\title{
FAKTOR VIRULENSI Salmonella enterica SEROVAR TYPHI
}

\author{
Anak Agung Gde Marvy Khrisna Pranamartha \\ Program Studi Pendidikan Dokter, Fakultas Kedokteran Universitas Udayana
}

(agungmarvy@gmail.com)

\section{ABSTRAK}

Demam tifoid disebabkan oleh bakteri Salmonella typhi, dengan gejala umum berupa demam tinggi dan nyeri perut. Tifoid adalah penyakit infeksi yang disebabkan oleh bakteri Salmonella typhi, yang masuk ke dalam tubuh melalui mulut dan saluran cerna. ${ }^{1}$

Untuk bisa memahami patogenesis dari demam tifoid sampai ke tingkat selular dan molekular, ada 5 hal penting yang harus digaris bawahi, yaitu:

1. Tipe 3 Sistem Sekresi (T3SS)

2. Virulence Genes dari Salmonella yang mengkode 5 SIP (Salmonella Invasion Protein) SIP A, B, C, $D$, dan E.

3. Toll R2 dan toll R3 yang merupakan lapisan luar dari makrofag.

4. Sistem imun lumen usus sampai ke organ dalam

5. Fungsi endotelial sel dalam inflamasi.

Infeksi Salmonella dapat berakibat fatal kepada bayi, balita, ibu hamil dan kandungannya serta orang lanjut usia. Hal ini disebabkan karena kekebalan tubuh mereka yang menurun. Virulensi salmonella tidak lepas dari peranan SPI, yang terletak di dalam kromosom dan plasmid bakteri.

Dimana SPI 1 dan SPI 2 telah dikaji cukup mendalam karena keterkaitannya dengan T3SS, dan berperan sangat penting pada invasi awal serta siklus hidup intrasel dari bakteri Salmonella.

Kontaminasi Salmonella dapat dicegah dengan mencuci tangan dan menjaga kebersihan makanan yang dikonsumsi. Selalu menjaga kebersihan lingkungan hidup kita agar terhindar dari kontaminasi dengan bakteri Salmonella typhi. Agar mewaspadai sejak dini pencegahan dan pengobatan penyakit typhus.

Studi mendalam perlu dilakukan agar kita mampu lebih memahami proses kompleks antara patogen dan sel inang. Mengingat dari 15 SPI yang sudah diketahui, hanya SPI 1 dan SPI 2 yang sudah dikaji secara mendalam.

Kata Kunci: Salmonella, Salmonella Invasion Protein, Typhi.

\section{PENDAHULUAN}

Salmonella disebarkan melalui makanan (foodborne diseases), dengan gejala diare, keram perut, dan demam dalam waktu 8-72 jam setelah memakan makanan yang terkontaminasi oleh Salmonella. Gejala lainnya adalah demam, sakit kepala, mual dan muntahmuntah. Tiga serotipe utama dari jenis $S$. enterica adalah S. typhi, S. typhimurium, dan S. enteritidis. S. typhi menyebabkan penyakit demam tifus (Typhoid fever), karena invasi bakteri ke dalam pembuluh darah dan gastroenteritis, yang disebabkan oleh keracunan makanan/intoksikasi. Gejala demam tifus meliputi demam, mual-mual, muntah dan kematian. S. typhi memiliki keunikan hanya menyerang manusia, dan tidak ada inang lain. Infeksi Salmonella dapat berakibat fatal kepada bayi, balita, ibu hamil dan kandungannya serta orang lanjut usia. Hal ini disebabkan karena kekebalan tubuh mereka yang menurun. Kontaminasi Salmonella dapat dicegah dengan mencuci tangan dan menjaga kebersihan makanan yang dikonsumsi.

S. typhi memiliki kombinasi karakteristik yang menjadikannya patogen efektif. Spesies ini berisi 
endotoksin khas dari organisme Gram negatif, serta antigen Vi yang ini diyakini akan meningkatkan virulensi. Serta memproduksi protein yang dikenal sebagai "invasin" yang memungkinkan sel-sel non-fagosit untuk mengambil bakteri, di mana ia dapat hidup intrasel. Hal ini juga mampu menghambat oksidatif leukosit, membuat respons imun tidak efektif.

\section{FAKTOR VIRULENSI}

Faktor resiko terbesar pada penyakit yang disebabkan oleh Salmonella typhi adalah mereka yang mempunyai kebiasaan kurang bersih dalam mengkonsumsi makanan, karena penyakit tipes dapat ditularkan melalui makanan dan minuman yang tercemar kuman tipes. Data menunjukkan bahwa tipes banyak menyerang anak usia 12-13 tahun (70\% - 80\%), pada usia 30-40 tahun (10\% - $20 \%$ ) dan diatas usia pada anak $12-13$ tahun sebanyak (5\% - 10\%). ${ }^{2}$

Namun untuk bisa memahami patogenesis dari demam tifoid sampai ke tingkat selular dan molekular, ada 5 hal penting yang harus digaris bawahi, yaitu:

1. Tipe 3 Sistem Sekresi (T3SS)

2. Virulence Genes dari Salmonella yang mengkode 5 SIP (Salmonella Invasion Protein) SIP A, B, C, D, dan $E$.

3. Toll R2 dan toll R3 yang merupakan lapisan luar dari makrofag.

4. Sistem imun lumen usus sampai ke organ dalam

5. Fungsi endotelial sel dalam inflamasi.

Type III protein secretion systems (T3SS)

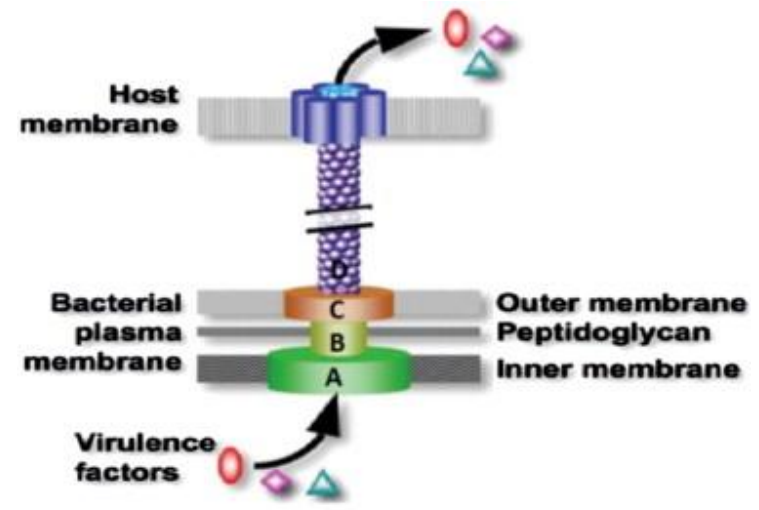

Gambar 1 Schematic type III secretion system (Zhang, dkk. 2008). ${ }^{3}$
A. The inner ring structure yang terdiri dari PrgHK protein subunits;

B. The cytoplasmic export machinery yang terdiri dari InvAC dan SpaPQRS

C. The outer ring structure yang terdiri dari InvGH

D. Bergabungnya A, B, dan C membentuk jarum molekular yang disebut inner rod structures, yang terdiri dari PrgJ dan Prgl subunits.

Walaupun disebut sebagai sistem sekresi, tapi T3SS bekerja dengan cara translasi, dimana protein dari sitoplasma bakteri, dipindahkan ke dalam sel inang..

\section{Salmonella Pathogenicity Island (SPI)}

Terjadinya adesi, invasi, dan injeksi toxin salmonella tidak lepas dari peranan SPI, yang terletak di dalam kromosom dan plasmid bakteri. Setiap kluster dari kromosom mengkode SPI yang berbeda beda.Sampai saat ini telah dipelajari kurang lebih 15 jenis SPI, namun hanya SPI 1 dan SPI 2 yang telah dikaji secara mendalam, karena keterkaitannya dengan T3SS (Zhang, dkk. 2008).

\section{Salmonella Pathogenicity Island 1 (SPI 1)}

SPI 1 mengandung material untuk invasi awal ke sel inang, setelah SPI 1 masuk ke dalam sel inan, kemudian berinteraksi dengan protein selular serta lemak di dalam sel inang.Pasien laki-laki, 6 tahun, beragama Hindu, Suku Bali, datang dengan keluhan panas badan sejak 5 hari yang lalu. Panas badan tidak diukur dengan termometer. Panas dirasakan naik turun, membaik dengan obat penurun panas. Riwayat menggigil dan kejang saat demam disangkal.

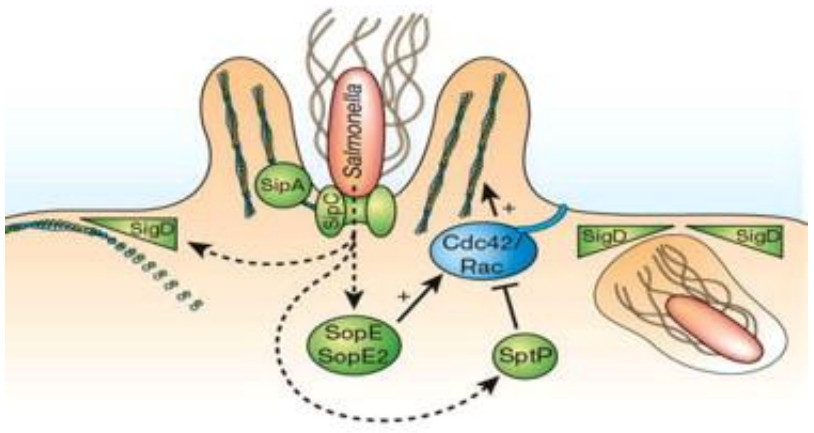

Gambar 2 Entry into host cells is mediated by the T3SS and its effectors encoded by SPI-1.

Struktur dasar dari T3SS terdiri dari: 
Dimana fungsi sel tersebut akan dimanipulasi guna kepentingan bakteri. Berikut beberapa contoh protein SPI 1 beserta fungsinya:

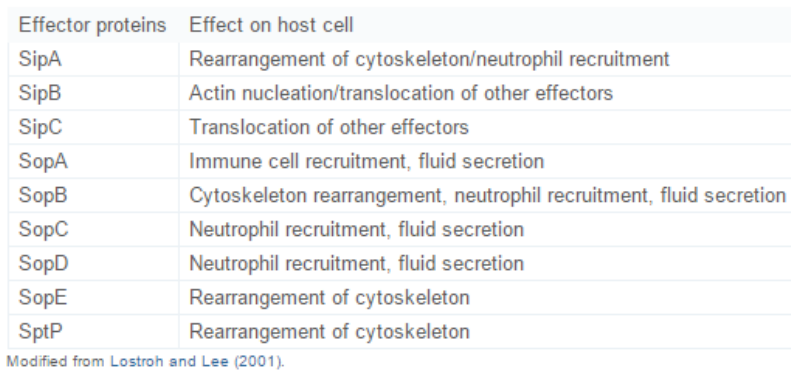

Tabel 1. Salmonella Pathogenicity Island 1 associated type III secretion system effector Proteins (Lostroh dan Lee, 2001). ${ }^{4}$

Misalnya SipA, SopB, SopE, dan SptP akan memodifikasi sitoskeleton sel host, sehingga sel epitelial akan ekstensi keluar dan terjadi proses engulfment, dimana bakteri Salmonella akan dibawa masuk ke dalam sel inang, dan dimulailah siklus hidup intraselular dari bakteri Salmonella.

\section{Salmonella Pathogenicity Island 2 (SPI 2)}

Proses intraselular dari bakteri salmonella, banyak diperantarai oleh SPI 2, dimana contohnya protein SifA, akan masuk ke dalam sel inang dan berinteraksi menjaga integritas dari vakuola bakteri, sehingga bakteri aman dari sistem imun tubuh.

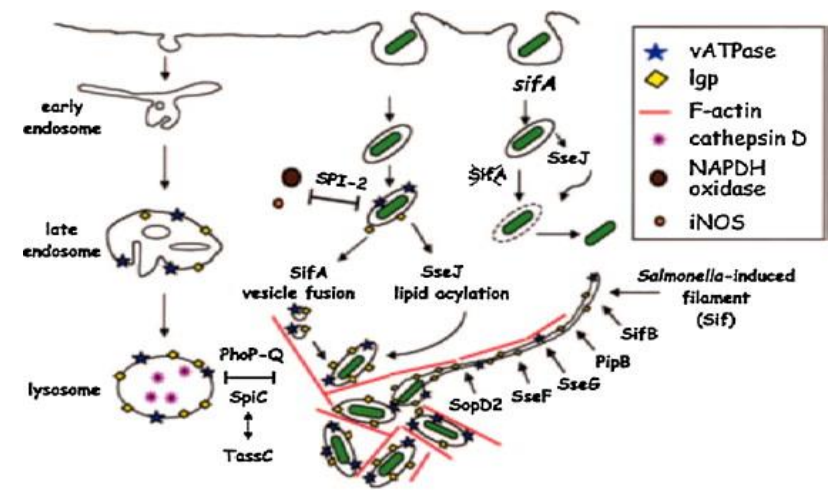

Gambar 3 Attachment and internalization of Salmonella in a host cell.

Berikut beberapa contoh protein SPI 2 beserta fungsinya:

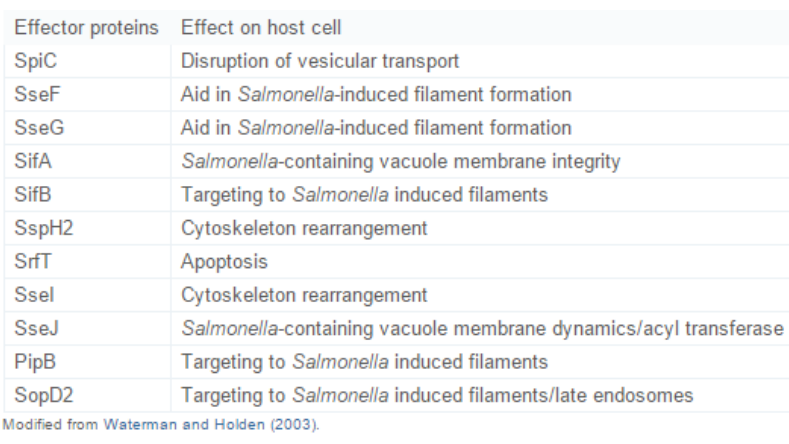

Tabel 2. Salmonella pathogenicity island 2 associated type III secretion system effector proteins (Waterman dan Holden. 2003). ${ }^{5}$

\section{DISKUSI}

Salmonella adalah penyebab utama dari penyakit yang disebarkan melalui makanan (foodborne diseases).Pada umumnya, serotipe Salmonella menyebabkan penyakit pada organ pencernaan. Salmonella typhi bisa berada dalam air, es, debu, sampah kering yang bila organisme ini masuk ke dalam vehicle yang cocok (daging, kerang dan sebagainya) akan berkembang biak mencapai dosis infeksi.

Infeksi Salmonella dapat berakibat fatal kepada bayi, balita, ibu hamil dan kandungannya serta orang lanjut usia. Hal ini disebabkan karena kekebalan tubuh mereka yang menurun. Virulensi salmonella tidak lepas dari peranan SPI, yang terletak di dalam kromosom dan plasmid bakteri.

Dimana SPI 1 dan SPI 2 telah dikaji cukup mendalam karena keterkaitannya dengan T3SS, dan berperan sangat penting pada invasi awal serta siklus hidup intrasel dari bakteri Salmonella.

\section{SIMPULAN DAN SARAN}

Kontaminasi Salmonella dapat dicegah dengan mencuci tangan dan menjaga kebersihan makanan yang dikonsumsi. Selalu menjaga kebersihan lingkungan hidup kita agar terhindar dari kontaminasi dengan bakteri Salmonella typhi. Agar mewaspadai sejak dini pencegahan dan pengobatan penyakit typhus.

Studi mendalam perlu dilakukan agar kita mampu lebih memahami proses kompleks antara patogen dan sel inang. Mengingat dari 15 SPI yang sudah diketahui, hanya SPI 1 dan SPI 2 yang sudah dikaji secara mendalam. 


\section{DAFTAR PUSTAKA}

1. Levine MM, Tacket CO, Sztein MB. HostSalmonella interaction: human trials. Microbes Infect 2001;3:1271-9.

2. Jasmine Kaur, S.K. Jain. 2012. Role of antigens and virulence factors of Salmonella enterica serovar Typhi in its pathogenesis. India: Department of Biotechnology, Hamdard University.

3. Zhang $X L$, Jeza VT, Pan Q. Salmonella Typhi: from a human pathogen to a vaccine vector. Cell Mol Immunol 2008;5(2):9.

4. Lostroh CP, Lee CA. The Salmonella pathogenicity island-1 type III secretion system. Microbes Infect 2001;3:1281-91.

5. Waterman SR, Holden DW. Functions and effectors of the Salmonella pathogenicity island 2 type III secretion system. Cell Microbiol 2003;5:501-11. 